\title{
GOSTUJOČI OBRAMBNI ATAŠEJI: PREDNOSTI IN POMANJKLIVOSTI
}

\section{ROVING DEFENCE ATTACHÉS: ADVANTAGES AND DISADVANTAGES}

Povzetek V sodobni obrambnodiplomatski praksi vse pogosteje zasledimo gostujoče obrambne atašeje. V večini držav so se pojavili kot posledica pritiskov po racionalizaciji diplomatske dejavnosti. V prispevku proučujemo prednosti in pomanjkljivosti gostujoče diplomacije, pri čemer poskušamo slednje relativizirati predvsem z vidikov naglega tehnološkega razvoja ter spremenjene miselnosti v mednarodnih odnosih na obrambnem področju. Izmed številnih prednosti največ pozornosti namenjamo vlogi gostujočih obrambnih atašejev v funkciji razvoja karierne diplomatske poti.

Ključne besede

Abstract In modern defence-diplomacy practice, we increasingly encounter roving defence attachés. In the majority of countries, they emerged as a result of the pressures to streamline diplomatic activities. In this paper, we study the advantages and disadvantages of roving diplomats, while trying to relativize the latter mainly from the point of view of rapid technological development and changed mind-set in international defence-related relations. Among the many advantages, major attention is devoted to the role of roving defence attachés in the development of diplomatic career paths.

Key words Diplomacy, defence diplomacy, roving defence attachés. 
Uvod Z zadnjo finančno krizo in gospodarsko recesijo so se povečale zahteve po racionalizaciji obrambnodiplomatske dejavnosti, vse več držav pa se po analogiji s tako imenovanimi letečimi veleposlaniki, ki pomenijo širše uveljavljeno in znano prakso v skandinavskih državah, odloča za akreditacije gostujočih obrambnih atašejev.

Razumljivo je, da se že v izhodišču pogosto postavlja vprašanje, ali so gostujoči obrambni atašeji funkcionalna oblika obrambnodiplomatskega delovanja, ki jo je smiselno vpeljati, uporabljati in razvijati. Najbolj nepremišljena opažanja in razumevanja so gotovo tista, ki imajo gostujoče pokrivanje le za boljše kot nikakršno. S tem se je težko strinjati, saj kakršna koli oblika akreditacije prinaša neke obveznosti in pričakovanja, ki jih je treba korektno in vestno izvajati. Gostujoči obrambni atašeji so glede diplomatskega statusa, privilegijev in imunitet izenačeni z rezidenčnimi diplomati, zaradi česar so tudi pričakovanja enakovredna in visoka.

V teoriji in praksi se največ pozornosti namenja zaskrbljenosti nad pomanjkljivostmi gostujočih atašejev, zato se pogosto zgodi, da povsem nenamerno prezremo njihove prednosti, pa čeprav so tudi slednje številne ter prinašajo zelo konkretne in neposredne učinke. V prispevku podrobneje predstavimo obe kategoriji, in sicer v razmerju do rezidenčnih diplomatov, ki ostajajo temeljni postulat obrambnodiplomatske prakse. Primerjavo razvijamo skozi dejavnost, vlogo in naloge sodobne obrambne diplomacije, ki se pod vplivom tehnološkega razvoja in spremenjene miselnosti v mednarodnih odnosih hitro in korenito spreminja, spremenjene okoliščine pa so delovanju gostujočih obrambnih atašejev vse bolj naklonjene.

\section{OBRAMBNA DIPLOMACIJA}

Diplomacija je družbena dejavnost in politični proces, skozi katerega politični udeleženci, najpogosteje države, stopajo v medsebojne odnose v mednarodnem okolju (Vukadinović, 1995, str. 110). Glede na ožji predmet obravnave se pojavljajo posebne vrste diplomacije, na primer ekonomska, gospodarska in kulturna, pa tudi obrambna. Področje delovanja slednje je veliko ožje in specializirano glede na splošno, visoki vojaški častniki in generali, ki to zvrst diplomacije opravljajo, pa naj bi poleg splošnega diplomatskega znanja in spretnosti premogli tudi specifično znanje z obrambnega in vojaškega področja.

Definicija, ki je značilna predvsem za anglosaške države, šteje za obrambno diplomacijo mirnodobno uporabo oborožene sile in z njo povezane infrastrukture kot orodja zunanje in varnostne politike ter vojaškega sodelovanja in pomoči (Aziri, 2012). Kocbek (1997) obrambno diplomacijo opredeljuje kot mirnodobno, normativno in usmerjeno diplomatsko oziroma zunanjepolitično dejavnost vlade, ki vključuje uporabo obrambnih in vojaških struktur zunaj državnega ozemlja. Njen cilj je krepitev obrambnega in vojaškega sodelovanja za graditev medsebojnega zaupanja ter večjo stabilnost in varnost v svetu. 
Številna razmišljanja v definicijo strne tudi Jazbec (2007), ki trdi, da je (dvostranska) obrambna diplomacija tista, ki:

- se kot dejavnost ukvarja z izvajanjem obrambne in vojaške ter tudi varnostne zunanje politike države pošiljateljice;

- ima za predmet obdelave vojaško-obrambne strukture države sprejemnice;

- ima namen vzpostavljati, razvijati in poglabljati odnose ter sodelovanje med tovrstnimi strukturami obeh držav;

- jo kot nosilec izvaja poseben diplomat, specializiran v poznavanju in obvladovanju vojaško-obrambnih zadev;

- pri svojem delu uporablja običajne diplomatske metode, ki so deloma prilagojene posebnostim področja, na katerem deluje;

- in katere izvajalec oziroma nosilec v diplomatskem predstavništvu deluje kot član osebja (kar na primeru gostujočih obrambnih atašejev velja le deloma).

Zanimiv pogled na obrambno diplomacijo predstavi Ogorec (2005), ki našteva osnovne naloge obrambnodiplomatskih predstavništev oziroma obrambnih atašejev:

- predstavljanje oboroženih sil in ministrstva za obrambo države pošiljateljice v državi sprejemnici;

- zaščita interesov države in oboroženih sil države pošiljateljice v državi sprejemnici (zaščita integritete pripadnikov, ki so v državi sprejemnici na različnih šolanjih in skupnih vojaških vajah ali skozi državo potujejo);

- zbiranje podatkov o oboroženih silah države sprejemnice;

- razvoj in krepitev dvostranskega sodelovanja na obrambnem in vojaškem področju, skladno z usmeritvami države pošiljateljice;

- svetovalna vloga: svetovanje veleposlaniku glede vprašanj vojaške narave.

\section{NAČINI AKREDITACIJE IN VRSTE OBRAMBNIH ATAŠEJEV}

Glede na način akreditacije razlikujemo tri vrste obrambnih atašejev:

- rezidenčne, ki začasno bivajo na ozemlju države, v kateri so akreditirani in so torej njeni rezidenti, naloge pa opravljajo na diplomatskem predstavništvu države pošiljateljice $\mathrm{v}$ državi sprejemnici. MO RS ima akreditiranih osem rezidenčnih obrambnih atašejev, in sicer $\mathrm{v}$ Bosni in Hercegovini, Italiji, na Kitajskem, v Nemčiji, Rusiji, Srbiji, Turčiji in ZDA;

- nerezidenčne, ki niso rezidenti države, v kateri so akreditirani, diplomatsko dejavnost pa opravljajo iz katere izmed sosednjih ali okoliških držav, vendar ne iz države pošiljateljice. Slovenski rezidenčni atašeji v obliki nerezidenčnih akreditacij pokrivajo osem držav: Dansko in Poljsko iz Berlina, Španijo iz Rima, Romunijo in Makedonijo iz Beograda, Kanado iz Washingtona ter Azerbajdžan in Libanon iz Ankare; 
- gostujoče ${ }^{1}$ oziroma nerezidenčne, s sedežem v državi pošiljateljici. Diplomatsko dejavnost izvajajo iz matične države, delovno mesto pa je sistemizirano v okviru ministrstva za obrambo, generalštaba oboroženih sil ali obveščevalnovarnostne službe. Na MO RS delujeta dva gostujoča atašeja. Prvi je akreditiran v Avstriji, Združenem kraljestvu, Švici in na Norveškem, drugi pa na Hrvaškem in Madžarskem.

Razlik glede postopkov akreditacije, statusa ${ }^{2}$ ter nalog in zadolžitev med posameznimi vrstami obrambnih atašejev ni, obstajajo pa razlike glede načinov ter temeljnih pristopov obrambnodiplomatskega delovanja.

V zadnjem času več predvsem zahodnoevropskih držav v obrambnodiplomatsko dejavnost vključuje gostujoče obrambne atašeje. Poglavitne razloge moramo iskati v dejstvu, da je bila zaradi vpliva svetovne gospodarske recesije in finančne krize večina obrambnih in vojaških sistemov prisiljena v občutno znižanje porabe, pri čemer so nekatere države prihranke iskale tudi s preoblikovanjem obrambnodiplomatskega pokrivanja, in sicer predvsem z ukinjanjem uradov rezidenčnih obrambnih atašejev. Ker so želele ohraniti določeno stopnjo diplomatskih stikov, so se odločile za gostujoče obrambne atašeje.

Po drugi strani so nekatere države zaradi širjenja članstva $\mathrm{v}$ mednarodnih organizacijah, predvsem v zvezi Nato in EU, vse več pozornosti začele namenjati in usmerjati v večstransko diplomacijo ter se pri tem zanašale, da bodo tudi zadeve $\mathrm{v}$ dvostranski domeni koordinirane in vodene prek nacionalnih obrambnih in vojaških predstavništev pri mednarodnih organizacijah. Praksa je hitro pokazala, da ni tako. Obseg dela $\mathrm{v}$ multilateralni diplomaciji je že $\mathrm{v}$ okviru rednih nalog intenziven, poleg tega pa so med dvostransko in večstransko diplomacijo pomembne razlike v načinih delovanja, zaradi česar obrambni predstavniki »klasične« diplomacije po večini niso vešči in spretni. Posledično so se države odločala, da obnovijo inštrumente dvostranske obrambne diplomacije, da njihove predhodne odločitve in poteze ne bi izpadle naivne in nepremišljene, pa so začele vzpostavljati mreže gostujočih obrambnih atašejev, ki predstavljajo nekakšen kompromis v primerih, ko rezidenčnega pokrivanja niso bile sposobne ponovno zagotoviti.

Z vidika gostujočih obrambnih atašejev je zanimiva študija Ženevskega centra za demokratični nadzor nad oboroženimi silami (DCAF) iz leta 2007, ki je raziskovala reformne smernice obrambne diplomacije po koncu hladne vojne. Obstajali naj bi

\footnotetext{
Za zdaj še nimamo enotnega termina ne v slovenskem ne v angleškem jeziku. V angleškem izrazoslovju se kot najbolj pogosta uporablja oznaka »roving" (potepanje, klatenje), redkeje pa »travelling « (potujoči) ali »laptop « (glede na prevladujočo vrsto računalnika, ki ga na pogostih službenih poteh uporabljajo). Na Madžarskem uporabljajo oznako regionalni ataše. Priročen je tudi izraz »roaming « (izposojen iz mobilne telefonije; gostovanje v tujini), iz katerega izhaja slovensko poimenovanje - gostujoči ataše.

2 Pravilnik o uslužbencih na obrambnem področju, ki začasno opravljajo delo v diplomatskih predstavništvih RS $v$ tujini, 3. člen, 5. odstavek: Uslužbenec na obrambnem področju, izenačen z diplomati, je v času, ko opravlja naloge obrambnega atašeja izven ozemlja RS, tudi gostujoči obrambni ataše, ki je akreditiran kot nerezidenčni obrambni ataše v sprejemnih državah s sedežem v Ljubljani.
} 
dve skupini držav. V prvi so tiste, katerih obrambnodiplomatski sistemi so zadnja desetletja ostali večinoma nespremenjeni. To so predvsem države, ki obrambno diplomacijo še naprej uporabljajo v glavnem za izvajanje obveščevalne dejavnosti. Druga skupina so članice zveze Nato in EU, katerih obrambnodiplomatske mreže so prešle znatne spremembe in prestrukturiranje, pri čemer rezultati raziskave nakazujejo šest osnovnih usmeritev:

- od dvostranskih obrambnih atašejev k večstranskim obrambnim predstavnikom pri regionalnih in mednarodnih organizacijah, kot so EU, OZN in zveza Nato;

- akreditacije v državah v razvoju namesto v razvitih državah; zavezništva, kot sta zveza Nato in EU, zmanjšujejo potrebo po vzajemnih akreditacijah obrambnih atašejev med članicami, odpirajo pa se uradi obrambnih atašejev v državah na Bližnjem vzhodu ter v Afriki in Aziji oziroma v državah, ki pridobivajo strateški pomen;

- od akreditacij v le eni državi k akreditacijam v več državah;

- od rezidenčnih obrambnih atašejev h gostujočim atašejem;

- od stalnih akreditacij k začasnim, časovno omejenim na projekt ${ }^{3}, \mathrm{v}$ okviru katerega je zaželena, potrebna ali koristna akreditacija obrambnega atašeja;

- od obrambnih atašejev k varnostnim (s širšega varnostnopolitičnega vidika so varnostni atašeji nekakšna kombinacija obrambnega in policijskega atašeja).

Poleg splošne usmeritve, ki govori o krepitvi gostujočih obrambnih atašejev, pa velja z vidika študije DCAF kot priporočilo izpostaviti tudi prizadevanja po akreditacijah $\mathrm{v}$ čim več državah in projektnih akreditacijah.

\section{POMANJKLJIVOSTI GOSTUJOČIH ATAŠEJEV}

V nadaljevanju predstavljamo pomanjkljivosti gostujočih obrambnih atašejev, hkrati pa poskušamo prepoznati načela in vzorce sodobnega diplomatskega delovanja, ki posamezne izmed njih relativizirajo, ublažijo ali odpravijo. Ob tem se je treba zavedati, da večina izmed naštetih pomanjkljivosti velja tudi za nerezidenčne obrambne atašeje.

Sistematičen pregled glavnih izzivov delovanja gostujočih atašejev dobimo, če nanje pogledamo skozi osnovne naloge obrambne diplomacije, ki sta jih definirala ter podrobno opredelila Nick (1997) in Sežun (2010). Po njunem mnenju obrambni atašeji opravljajo dve vrsti nalog: strokovno-funkcionalne in reprezentativno-protokolarne.

V okviru strokovno-funkcionalnih nalog obrambni ataše opravlja obveščevalno funkcijo (zbira podatke in pripravlja poročila o obrambno-vojaških aktivnostih države sprejemnice) ter komunikacijsko funkcijo (vzpostavlja in usmerja stike, ki so podlaga za povezovanje in sodelovanje). V okviru obeh funkcij gostujoči ataše nedvomno občuti določen primanjkljaj, ki izvira iz nestalne prisotnosti v sprejemni državi.

3 Kot primer lahko navedemo akreditacijo madžarskega obrambnega atašeja na Švedskem, v času, ko je podjetje Saab madžarskim obrambnim silam dobavljalo lovska letala JAS-39 gripen (Gombos, 2015). 
Le občasna prisotnost $\mathrm{v}$ sprejemni državi je glavna ovira, da gostujoči ataše veliko težje vzpostavi pristno, osebno in neformalno komunikacijo s predstavniki obrambnega ministrstva ter pripadniki oboroženih sil kot tudi drugimi predstavniki obrambnodiplomatskega zbora. Zaradi navedenega dejstva gostujoči obrambni atašeji po mnenju Zupančiča (2010) niso zmožni in sposobni vzpostavljanja socialnih in strokovnih mrež.

Pogosto se pomembne informacije oblikujejo in širijo prav v okviru omenjenih struktur ter razmeroma zaprtih skupin diplomatov in obrambnih strokovnjakov, do katerih imajo gostujoči atašeji omejen dostop. Hkrati se je treba zavedati, da je tudi dostop do ustreznih ravni odločanja pogosto odvisen predvsem od kakovosti kolegialnih in prijateljskih odnosov, pri čemer navedene omejitve prinašajo dodatne izzive pri vzpostavljanju pristnih osebnih stikov.

Pomanjkljivosti gostujočih atašejev z vidika dostopa do informacij in učinkovite komunikacije se relativizirajo ob dejstvu, da se je vloga obrambne diplomacije $\mathrm{v}$ minulih letih bistveno spremenila. Kot ugotavlja Tratnik (2012), so tehnični napredek ter razmah in množična uporaba svetovnega spleta omogočili večji in hitrejši dostop do skoraj vseh podatkov in informacij, pri čemer jih tudi obrambni atašeji vse več pridobijo iz javnih virov. Na tej podlagi se avtorica utemeljeno vpraša, ali bodo $\mathrm{v}$ prihodnosti obrambnodiplomatski predstavniki v državi sprejemnici (rezidenčni atašeji) sploh še potrebni.

Zaradi razmaha medijev množičnega obveščanja, dostopnosti interneta ter premika miselnih vzorcev od nezaupanja ter odkritih vojaških napetosti in konfrontacij $h$ kulturi sodelovanja in partnerstva (še posebej v okviru zavezništev) v sodobnem svetu obstajajo le še redke informacije, ki niso javno dostopne. Če je obrambni ataše še v času hladne vojne z vsemi dovoljenimi in nedovoljenimi sredstvi pridobival informacije, na primer o številu oklepnih bojnih vozil (tipih oborožitve in količinah), ki jih poseduje neka država, $\mathrm{v}$ sodobnem času zadostuje že nagel vpogled $\mathrm{v}$ spletne baze, za zanesljivejše in verodostojnejše podatke pa listanje specializiranih vojaških almanahov. Obveščevalno funkcijo obrambnih atašejev v pretežni meri opravljajo mednarodne pogodbe o trgovini z orožjem, razoroževanju in nadzoru nad oboroževanjem, z obdobnimi poročanji in mednarodnimi inšpekcijami, medtem ko o stopnji pripravljenosti pričajo udeležbe na mednarodnih vojaških usposabljanjih in vajah.

Podobno idejo zasledimo pri Zupančiču (2010, str. 68), ki trdi, da je spekter nalog vojaških diplomatov zelo širok, a se skozi čas spreminja. Prevladujoča obveščevalna funkcija, ki je bila značilna od začetkov vzpostavitve tovrstnega inštituta do konca hladne vojne, izgublja pomen, nadomešča pa jo komunikacijska funkcija, ki je bistvena za povezovanje in sodelovanje. Obveščevalno dejavnost prvenstveno in neposredno izvajajo pristojne obveščevalne službe, ki jih atašeji samo občasno dopolnjujejo in jim pomagajo pri iskanju ustreznih virov informacij. 
Sodobne tehnologije vnašajo korenite spremembe na področje komunikacij in vplivajo tudi na komunikacijsko dejavnost obrambnih atašejev. Uradne diplomatske note nadomeščajo in izpodrivajo poluradna sporočila, ki so posredovana po elektronski pošti, različnih mobilnih aplikacijah ali celo družabnih omrežjih. V duhu tesnega sodelovanja in partnerstva delovna komunikacija navadno ne poteka več prek kodiranih in strogo varovanih omrežij, če že, pa tudi slednja omogočajo bistveno večjo prilagodljivost glede ustvarjanja in sprejemanja sporočil. Hkrati so na voljo nova sredstva in mediji, kot na primer različne avdio-video povezave ter mobilna podatkovna omrežja, ki omogočajo interaktivno komunikacijo. Kot ugotavlja Mogolič (2004), je za sodobno (postmoderno) vojaško organizacijo značilno, da se odzove na vplive iz civilnega okolja ter tako kot posamezniki in družba kot celota postaja vse manj zaprta, birokratska in hierarhična struktura, v kateri tudi nekdaj dominantne formalne vezi vse pogosteje prehajajo v osebne. $\mathrm{Ob}$ vse tesnejši povezanosti in prepletenosti civilnega in vojaškega okolja ter vse večji internacionalizaciji oboroženih sil postaja tudi komunikacija vse bolj odprta.

Kot pomanjkljivost gostujočih atašejev v okviru funkcionalnih nalog velja izpostaviti zaščito integritete pripadnikov oboroženih sil države pošiljateljice, ki so v državi sprejemnici na različnih šolanjih ali skupnih vojaških vajah, lahko pa tudi le potujejo čez njeno ozemlje. Ob zapletih, na primer ob zdravstvenih poškodbah ali prometnih nesrečah, so navadno potrebni takojšnji odzivi in ukrepi obrambnega atašeja ter osebna prisotnost na kraju dogodka, česar gostujoči atašeji ne morejo zagotoviti. V njihovo obrambo pričajo podatki, da so izredni dogodki redki, poleg tega pa status oboroženih sil na ozemlju tuje države in nabor ob izrednih dogodkih podrobno določajo predmetni mednarodni pravni sporazumi, tako imenovani sporazumi SOFA $^{4}$ ). Poleg tega lahko posamezniki, da bi se izognili različnim tveganjem, sklenejo ustrezno zavarovanje za tujino. Pri zapletih širšega obsega pa mednarodno diplomatsko in konzularno pravo ${ }^{5}$ omogoča vzpostavitev tako imenovanih specialnih misij. To so začasne misije, ki jih ena država pošilja v drugo zaradi obravnavanja določenih vprašanj ali izvršitve povsem določene naloge. So najstarejša in zelo prožna oblika diplomatskega občevanja, primerna tudi za sodoben tempo življenja (Bohte in Sancin, 2006, 191).

Gostujoči atašeji so omejeni tudi pri opravljanju reprezentativno-protokolarnih nalog. Zaradi le občasne prisotnosti v sprejemni državi se ne morejo udeležiti vseh sprejemov, poročanj, informiranj za visoke goste v okviru vojaških vaj ter podobnih dogodkov, ki jih organizirajo pristojne službe ministrstva ali generalštaba ter tudi posamezna veleposlaništva, ki so prisotna v državi sprejemnici.

Toda skladno s sodobnimi trendi diplomatske dejavnosti se organizira vse manj dogodkov, ki so izključno protokolarne narave, temveč so slednji navadno dodani širšim informativnim poročanjem in aktivnostim strokovnega značaja. Ker so v

\footnotetext{
4 Status of Forces Agreement (SOFA).

5 Dunajska konvencija o diplomatskih odnosih.
} 
nekaterih majhnih državah, vključno s Slovenijo, večinoma akreditirani nerezidenčni in gostujoči atašeji, so jim začeli prilagajati sistem poročanj, pa tudi druge dogodke, vključene v letne programe. To omogoča pravočasno načrtovanje in udeležbo tudi gostujočim atašejem. Kljub vsemu velja opozoriti na potrebo in smiselnost redne prisotnosti gostujočega atašeja v sprejemnih državah, ustrezno organizacijo in razporeditev dela ter oblikovanje prioritet (udeležba na vseh dogodkih ni potrebna). Dodatne priložnosti z vidika obveščanja omogočajo tudi članstva in srečanja v okviru združenj obrambnih atašejev ter delovni sestanki ožjih interesnih skupin, na primer srečanja obrambnih atašejev iz držav članic zveze Nato. Koristen vir informacij so tudi srečanja s starešinami obrambnodiplomatskih zborov.

Kot zadnjo izmed pomanjkljivosti velja omeniti, da akreditacija gostujočega atašeja nalaga dodatne naloge in obveznosti rezidenčnemu veleposlaništvu. Diplomatska praksa določa, da uradna komunikacija poteka na relaciji med MZZ države sprejemnice in veleposlaništvom države pošiljateljice, pri čemer morajo v odsotnosti rezidenčnega atašeja drugi uslužbenci veleposlaništva prevzeti dodatne zadolžitve in obveznosti. V glavnem gre res za rutinske, tehnične in administrative zadeve, na primer posredovanje pošte, vendar pa kljub vsemu zahtevajo resen in odgovoren odziv.

\section{PREDNOSTI GOSTUJOČIH ATAŠEJEV}

V majhnih državah z omejenim diplomatskim aparatom, brez specializiranih izobraževanj in usposabljanj ter diplomatske akademije je lahko glavna prednost gostujočih atašejev njihova vloga $\mathrm{v}$ funkciji razvoja karierne diplomatske poti. Ustrezno organiziran sistem gostujočih atašejev z vzpostavljenim mentorskim odnosom lahko uporabimo za usposabljanje ter izbor kandidatov, ki bodo sposobni kakovostno in učinkovito opravljati najzahtevnejše (rezidenčne) diplomatske naloge. Z razvojem karierne poti skozi gostujoče atašeje bi hkrati pomladili diplomatski zbor, omogočili celovite priprave bodočih rezidenčnih diplomatov, zagotovili polno operativnost ob nastopu funkcije, povečali delovno motivacijo ter preprečili možnosti, da diplomatske funkcije zasedejo neprimerni kandidati, brez izkušenj ter ustreznih znanj in spretnosti. Zavedati se je namreč treba, da lahko zahteven diplomatski poklic uspešno in učinkovito opravljajo le najbolje usposobljeni, strokovni, vestni in predani posamezniki.

Ena izmed najbolj očitnih in najširše prepoznanih prednosti gostujočih atašejev je finančna racionalizacija diplomatskega delovanja. Stroški rezidenčnega obrambnega atašeja zadostujejo za delovanje najmanj treh gostujočih atašejev ${ }^{6}$.

\footnotetext{
${ }^{6}$ Po izračunih finančnih analitikov MO RS so letni stroški slovenskega rezidenčnega obrambnega atašeja v povprečju okoli 150.000 evrov (stroški se med posameznimi atašeji precej razlikujejo, saj so odvisni od velikosti diplomatove družine, števila šoloobveznih otrok ter indeksa cen življenjskih potrebščin v državi sprejemnici), stroški delovanja gostujočega atašeja na letni ravni pa ne presežejo 40.000 evrov.
} 
Gostujoči atašeji so akreditirani v več državah kot rezidenčni. Omenjeno potrjuje slovenski primer, saj so rezidenčni obrambni atašeji v povprečju akreditirani $\mathrm{v}$ dveh državah, gostujoča pa v treh. Mogoče še bolj zgovoren je podatek, da je RS še pred nekaj leti imela rezidenčna obrambna atašeja na Hrvaškem in Madžarskem, akreditirana izključno v sprejemni državi, medtem ko je trenutno v obeh državah akreditiran isti gostujoči ataše.

Nadomeščanje rezidenčnih atašejev z gostujočimi omogoča preusmeritev rezidenčnega pokrivanja na države, $\mathrm{v}$ katerih je diplomatska prisotnost $\mathrm{v}$ nekem obdobju bolj smiselna, potrebna in koristna. Če Avstrija tako krepi rezidenčno prisotnost $\mathrm{v}$ državah na evropski periferiji, na morebitnih kriznih žariščih ter v državah, v katerih se izvajajo mednarodne mirovne operacije s prisotnostjo pripadnikov Avstrijske zvezne vojske (Rottenberger, 2014), pa je Slovenija pozornost preusmerila na države, ki pridobivajo politični in geostrateški pomen. Tako so umiki atašejev iz Budimpešte, Londona, Pariza, Zagreba in Skopja omogočili akreditaciji v Pekingu in Ankari.

Gostujoči ataše ni na nobeno izmed akreditiranih držav vezan življenjsko in bivanjsko ter tako vpet $\mathrm{v}$ njeno vsakodnevno politično, družbeno in kulturno dogajanje. Obstajata namreč past in nevarnost, da rezidenčni diplomat dogajanje $\mathrm{v}$ državi akreditacije in njeni okolici začne spremljati in razumeti predvsem skozi prizmo družbenih in političnih stereotipov ter interesov gostujoče države, zaradi česar so njegova dejanja lahko subjektivna in pristranska. Gostujoči diplomati so pri svojem delu bolj objektivni in vsem državam akreditacije načeloma namenjajo enako ali podobno veliko pozornosti.

Z akreditacijo atašeja iz prestolnice se izognemo negativnim odzivom in diplomatski nejevolji, ki bijih lahko povzročila nerezidenčna akreditacija iz katere izmed okoliških držav, predvsem, kadar so njuni medsebojni odnosi obremenjeni z zgodovinskimi okoliščinami ali nerešenimi vprašanji, ki se v času koakreditacije ${ }^{7}$ lahko šele pojavijo. Na primer Portugalska odkrito zavrača koakreditacije iz Španije (Longar, 2015), pa tudi slovensko zunanjepolitično stališče ni naklonjeno koakreditacijam diplomatov v RS iz Hrvaške. Na splošno so države bolj naklonjene gostujočim akreditacijam kot koakreditacijam, saj slednje vendarle na neki način odražajo razmerje podrejenosti in perifernosti.

Po ugotovitvah Zupančiča (2010) je eden temeljnih izzivov rezidenčnih obrambnih atašejev odstopanje od načela enostarešinstva. Po strokovni liniji je atašeju neposredno nadrejen obrambni minister ali načelnik generalštaba, kot diplomat pa je, vsaj neformalno, podrejen vodji diplomatske misije oziroma veleposlaniku. Slednji v sprejemni državi predstavlja predsednika republike, predsednik republike pa je skladno z Ustavo Republike Slovenije (102. člen, funkcija predsednika

Diplomati so hkrati lahko akreditirani v več državah. Za države zunaj sedeža diplomatskega predstavništva se je uveljavil izraz, da so v njih koakreditirani. 
republike) vrhovni poveljnik obrambnih sil oziroma Slovenske vojske, katere pripadnik je obrambi ataše. Tudi gostujoči ataše je del ekipe veleposlaništva, vendar veleposlaniku ni podrejen. $\mathrm{Z}$ akreditacijo gostujočega atašeja vodjo diplomatske misije izločimo iz linije vodenja oziroma poveljevanja v smislu subordinacije, s čimer se izognemo morebitnim trenjem, nesoglasjem, obtoževanjem in prepirom na relaciji med veleposlanikom in obrambnim atašejem, do katerih lahko prihaja v praksi (predvsem v primerih, ko so za obrambne atašeje imenovani pripadniki najvišjih častniških ali generalskih činov).

Gostujoči ataše v primerjavi s kolegi na oddaljenih lokacijah deli pisarno z najbližjimi sodelavci, neposredno nadrejenimi in vršnim menedžmentom. Glede nalog dobiva na rednih delovnih in strokovnih sestankih natančna navodila in usmeritve, ki se lahko kadar koli dodatno in podrobneje pojasnijo ter razložijo. Omogočena sta mu tudi neposreden dostop do vsebinskih gradiv in široka strokovna podpora. Zaradi neposredne vključenosti opravlja dane naloge zavzeto ter si jih prizadeva dokončati kakovostno in celovito. Hkrati nadrejeni lažje izvajajo nadzor nad njegovim delom ter vzpostavijo konsistentnejša merila delovne uspešnosti in učinkovitosti. Kot potrjuje Jazbec (2007), je za dobro delovanje obrambnih atašejev zelo pomembno, da jih ministrstvo sproti, stalno in natančno inštruira ter jim daje konkretne naloge, kar je gotovo lažje z gostujočimi obrambnimi atašeji.

Kadar se država odloča za prvo napotitev rezidenčnega obrambnega atašeja, jo zlahka lahko zavedejo nerealne ocene ter razkorak med pričakovanji in resničnimi potrebami. Dobro bi bilo preveriti praktično stanje na terenu, kar lahko opravimo S »predhodnico« v obliki gostujočega atašeja. Če se naknadno izkaže, da je rezidenčni ataše nepotreben in nekoristen, navadno izgubimo celoten (večletni) mandat, saj predčasen odpoklic pošilja mešane, predvsem negativne, signale in ga države uporabljajo le izjemoma. Neobičajna je celo akreditacija atašeja za le en mandat. »Preizkušanje terena $\mathrm{z}$ gostujočim atašejem je gotovo najbolj preudarna in racionalna rešitev, saj je njegova akreditacija prilagodljiva ter ima tudi v najslabšem primeru minimalne finančne in diplomatske posledice.

Včasih akreditacija atašeja $\mathrm{v}$ določeni državi na dolgi rok ni potrebna, lahko pa se v nekem trenutku pojavijo specifične okoliščine ali projekti posebnega pomena, ki ustvarijo potrebo po začasni akreditaciji. V tovrstnih primerih je najbolj ustrezna prav akreditacija gostujočega atašeja, ki lahko na kratek rok začne in zaključi svoj mandat, za nastop dela pa niso potrebne daljše priprave, selitev ter vnaprejšnja ureditev namestitvenih in delovnih pogojev. Gostujoči ataše lahko začne opravljati naloge skoraj isti dan, ko mu je izdana akreditacija sprejemne države, ter konča s trenutkom, ko akreditacija ni več potrebna ali koristna.

Gostujoči obrambni atašeji delujejo in bivajo v domačem okolju, kar posameznikom v določenem življenjskem obdobju ustreza bolj, kot bi jim selitev v tujino. V primeru gostujoče akreditacije ni potrebe, da bi se diplomatski dejavnosti prilagodili življenjski cikel in navade celotne družine. Po drugi strani obstaja utemeljeno 
tveganje, da zaradi začasne nezmožnosti ali nezainteresiranosti za selitev v tujino izgubimo kakovostnega kandidata za opravljanje diplomatske funkcije.

Če smo pri pomanjkljivostih ugotovili, da večina prizadene tudi nerezidenčne obrambne atašeje, pa velika večina prednosti pripada le gostujočim atašejem. Pogojno lahko z nerezidenčnimi akreditacijami preverimo potrebo po napotitvi rezidenčnega atašeja oziroma zagotovimo akreditacijo za določen čas ali projekt. Glede prve je dodaten izziv dejstvo, da rezidenčne akreditacije navadno niso zgoščene na prostoru, glede druge pa smo omejeni, če ne zagotavljamo rezidenčnega pokrivanja v neposredni soseščini.

\section{Priporočila in sklepi}

Da gostujoči obrambni atašeji omogočajo funkcionalno obrambnodiplomatsko delovanje, potrjujeta razmeroma bogata praksa ter postopna in vztrajna širitev kroga držav, ki uporabljajo ta koncept. Hkrati države, ki inštitut že uporabljajo, povečini širijo obseg akreditacij.

Analiza delovanja gostujočih obrambnih atašejev na MO RS še ni bila narejena. Da so prve ocene v pretežni meri pozitivne, pa lahko sklepamo na podlagi razmišljanj o širitvi diplomatske dejavnosti z atašeji iz prestolnice. Tovrstni načrti so namreč vključeni v srednjeročni obrambni program, ki je eden izmed temeljnih strateških načrtovalnih in razvojnih dokumentov. Skladno s Srednjeročnim obrambnim programom Republike Slovenije 2016-2020 naj bi se »obrambnodiplomatska mreža prilagodila zunanjepolitičnemu položaju RS in izvajanju nalog SV v spremenjenih mednarodnih politično-varnostnih razmerah $\mathrm{z}$ regionalno naravnanostjo in jasno izraženim težiščem sodelovanja. Zagotovljeni bodo ustrezni kadrovski viri za popolnitev obrambnodiplomatske mreže in intenzivirana uporaba gostujočih (nerezidenčnih) atašejev«.

Ne smemo pa prezreti, da se pri gostujočih atašejih v primerjavi z rezidenčnimi pojavljajo primanjkljaji, pomanjkljivosti, izzivi oziroma težave pri opravljanju tako strokovno-funkcionalne kot reprezentativno-protokolarne funkcije, vendar pa se tovrstna tveganja lahko bistveno zmanjšajo že z ustrezno organizacijo dela. Dodatno jih je mogoče relativizirati z vidika informacijske družbe oziroma širokega dostopa do informacij ter uporabe sodobnih informacijskih in komunikacijskih tehnologij. Da je obrambna diplomacija doživela korenite evolucijske spremembe in postala bistveno manj agresivna, pa je tudi posledica povečanega zaupanja in spremenjene miselnosti mednarodnih odnosov, predvsem po koncu hladne vojne, ki iščejo svoje poslanstvo $\mathrm{v}$ prizadevanjih za povezovanje in sodelovanje.

Hkrati gostujoči obrambni atašeji prinašajo več povsem konkretnih prednosti, pri čemer pa se nekatere pokažejo šele v specifičnih okoliščinah ali povsem konkretno izraženem namenu in interesu. Zato bi veljalo oblikovati jasna pričakovanja ter proučiti specifične dejavnike in parametre posameznih akreditacij, na podlagi katerih 
bi lahko ocenili, ali bo akreditacija gostujočega obrambnega atašeja v sprejemni državi omogočala funkcionalno opravljanje diplomatskih nalog.

Kot eno izmed glavnih prednosti gostujočih atašejev velja izpostaviti morebitno vlogo v funkciji razvoja karierne diplomatske poti. Diplomat bi v pisarno gostujočih atašejev vstopil kot pripravnik, se usposobil in izpopolnil, prevzel rezidenčno diplomatsko funkcijo ter se v pisarno gostujočih atašejev vrnil kot mentor. Tako bi v postopke izbire bodočih diplomatov vnesli več transparentnosti in izkoreninili pogosto negativno kadrovsko selekcijo.

\section{Literatura}

1. Aziri, F., 2012. Obrambna diplomacija kot sredstvo zagotavljanja varnosti - Primer Republike Makedonije (Magistrsko delo). Ljubljana: Fakulteta za družbene vede.

2. Bohte, B. in Sancin, V., 2006. Diplomatsko in konzularno pravo. Ljubljana: Cankarjeva založba.

3. Defence Attachés, DCAF Backgrounder Series, 2007. Ženeva: Geneva Centre for the Democratic Control of Armed Forces.

4. Dunajska konvencija o diplomatskih odnosih, 2013. Uradni list RS (9).

5. Gombos, A., 2015. Intervju o organizaciji sistema gostujočih obrambnih atašejev na Madžarskem. Ljubljana, 8. september 2015.

6. Jazbec, M., 2007. Vojaška in obrambna diplomacija. Ljubljana: Fakulteta za družbene vede.

7. Kocbek, A., 2007. Preoblikovanje obrambne diplomacije. Bilten Slovenske vojske, 9 (1), 73-90.

8. Longar, M., 2015. Intervju o izkušnjah »letečega« veleposlanika. Ljubljana, 3. november 2015.

9. Mogolič, F., 2004. Rituali v vojaški organizaciji (Diplomsko delo). Univerza v Ljubljani: Fakulteta za družbene vede.

10. Nick, S., 1997. Diplomacija: Metode i tehnike. Zagreb: Barbat.

11. Ogorec, M., 2005. Vojno-diplomatska praksa. Zagreb: Golden marketing-tehnička knjiga.

12. Pravilnik o uslužbencih na obrambnem področju, ki začasno opravljajo delo v diplomatskih predstavništvih Republike Slovenije v tujini, 2011. Interni pravni akt Ministrstva za obrambo Republike Slovenije.

13. Rottenberger, N., 2014. Militärdiplomatie: Verteidigungsattaché Roving Ein flexibles Modell der Militärdiplomatie. Truppendienst, št. 342 (6/2014), 514-519.

14. Sežun, D., 2010. Spreminjanje vloge vojaškega atašeja kot obvě̌čevalnega dejavnika (Magistrsko delo), Kranj: Fakulteta za države in evropske študije.

15. Tratnik, K., 2012. Prihodnost slovenske obrambne diplomacije (Diplomsko delo). Univerza v Mariboru: Fakulteta za varnostne vede.

16. Ustava Republike Slovenije, 2013. Uradni list RS, (47). Neuradno prečiščeno besedilo. Pridobljeno 15. 1. 2016 na http://www.us-rs.si/o-sodiscu/pravna-podlaga/ustava/.

17. Vlada Republike Slovenije, 2016. Srednjeročni obrambni program Republike Slovenije 2016-2020. Pridobljeno 20. 2. 2016 na http://www.mo.gov.si/fileadmin/mo.gov.si/ pageuploads/pdf/predpisi/obramba/SOPR2016_2020.pdf.

18. Vukadinović, R., 1995. Diplomacija: strategija političnih pogajanj. Ljubljana: Arah consulting (Zbirka Preobrazbe).

19. Zupančič, M., 2010. Vojaški ataše - na razpotju med vojaško organizacijo in civilnim okoljem (Magistrsko delo). Univerza na Primorskem: Fakulteta za management. 